\title{
Macronutrients in watermelon plants fertilized with potassium and cattle manure
}

\author{
José A. M. do Nascimento ${ }^{1}$, Jacob S. Souto ${ }^{2}$, Walter E. Pereira ${ }^{3}$, \\ Sherly A. da S. Medeiros ${ }^{4} \&$ Lourival F. Cavalcante ${ }^{4}$ \\ ${ }^{1}$ Instituto Federal do Ceará. Tianguá, CE. E-mail: adeilson.nascimento@ifce.edu.br (Corresponding author) \\ ${ }^{2}$ Universidade Federal de Campina Grande/Centro de Saúde e Tecnologia Rural/Unidade Acadêmica de Engenharia Florestal. Patos, PB. E-mail: \\ jacob_souto@uol.com.br \\ ${ }^{3}$ Universidade Federal da Paraíba/Centro de Ciências Agrárias/Departamento de Ciências Fundamentais e Sociais. Areia, PB. E-mail: wep@cca.ufpb.br \\ ${ }^{4}$ Universidade Federal da Paraíba/Centro de Ciências Agrárias/Programa de Pós-Graduação em Agronomia. Areia, PB. E-mail: sherly.agro@hotmail.com; \\ lofeca@cca.ufpb.br
}

\section{Key words:}

Citrullus lanatus

organic matter

mineral nutrition

\begin{abstract}
A B S T R A C T
Potassium is the nutrient required in greatest quantity by watermelon, especially during the production phase. Therefore, the aim of this experiment was to evaluate the effect of potassium and cattle manure doses on the nutritional composition of 'Crimson Sweet' watermelon plants. The treatments were arranged in a randomized block design with three replicates and 21 plants per plot using a $3 \times 5+1$ factorial scheme, referring to three manure doses $\left(0 ; 1,100\right.$ and 2,520 $\left.\mathrm{g} \mathrm{hole}^{-1}\right)$, in order to increment the level of soil organic matter from 0.67 present in the soil to 3.0 and $6.0 \%$, five potassium doses $\left(0,7.5,15,22.5\right.$ and $\left.30 \mathrm{~kg} \mathrm{ha}^{-1}\right)$ in the form of potassium chloride and one additional treatment (without organic and mineral fertilization). At the beginning of fruiting, leaves were collected to evaluate the nutritional status of the plants in macronutrients. According to the results, cattle manure stimulates the absorption of macronutrients by watermelon; in soil with $3.0 \%$ of organic matter, the best results corresponded to the $\mathrm{K}_{2} \mathrm{O}$ dose of $15 \mathrm{~kg} \mathrm{ha}^{-1}$ and, for $6.0 \%$, between 11 and $13 \mathrm{~kg} \mathrm{ha}^{-1}$.
\end{abstract}

\section{Palavras-chave: \\ Citrullus lanatus matéria orgânica nutrição mineral}

\section{Macronutrientes em plantas de melancia adubadas com potássio e esterco bovino}

\begin{abstract}
R E S U M O
O potássio é o nutriente mineral exigido em maior quantidade pela melancieira principalmente na fase de produção. Este trabalho objetivou avaliar o efeito de doses de potássio e esterco bovino na composição foliar de melancieira. Os tratamentos foram distribuídos em blocos ao acaso com três repetições e 21 plantas por parcela em arranjo fatorial $3 \times 5+1$, referentes às três doses de esterco bovino $0 ; 1.100$ e $2.520 \mathrm{~g} \mathrm{cova}^{-1}$ ), para elevar o teor de matéria orgânica de $0,67 \%$ que o solo possuía, para 3 e $6 \%$, cinco doses de $\mathrm{K}_{2} \mathrm{O}\left(0 ; 7,5 ; 15 ; 22,5\right.$ e $\left.30 \mathrm{~kg} \mathrm{ha}^{-1}\right)$ utilizando-se $\mathrm{KCl}$ como fonte e um tratamento adicional (sem adubação orgânica e mineral). No início da frutificação foram colhidas folhas para avaliação do estado nutricional das plantas em macronutrientes (N, P, K, Ca, Mg e S). O esterco bovino estimula a absorção de macronutrientes pela melancieira; no solo com $3 \%$ de matéria orgânica os melhores resultados corresponderam à dose de $\mathrm{K}_{2} \mathrm{O}$ de $15 \mathrm{~kg} \mathrm{ha}^{-1}$ e para $6 \%$ entre 11 e $13 \mathrm{~kg} \mathrm{ha}^{-1}$.
\end{abstract}




\section{INTRODUCTION}

The mineral nutrition of watermelon [Citrullus lanatus (Thunb.) Matsum. \& Nakai] is one of the factors that mostly contribute the most to the increase in yield and production quality of this crop, which stands out for exporting large amounts of nutrients, and potassium is the nutrient most extracted from 45 to 65 days after transplanting (Gonsalves et al., 2011; Almeida et al., 2012).

The adequate supply of $\mathrm{K}$ to watermelon increments the contents of the element in leaf dry matter and stimulates the absorption of other essential nutrients (El-Bassiony et al., 2012). For this, Cavalcanti (2008) recommends doses between 30 and $60 \mathrm{~kg} \mathrm{ha}^{-1}$ of $\mathrm{K}_{2} \mathrm{O}$, in the state of Pernambuco. In other northeastern states, such as Paraíba, the manuals of recommendation are scarce or outdated and become an obstacle for the expansion of local crops, warning for the necessity of studies with fertilization in local crops.

Besides mineral fertilization, the supply of organic matter to the soil is of great importance for the cultivation of watermelon and other vegetables, especially in sandy soils of arid regions that have low contents, because the climate conditions favor the acceleration of oxidation of soil organic matter (Nicolae et al., 2014).

Most producers of vegetables in the state of Paraíba, according to Silva et al. (2011), use cattle manure as the only source of nutrient for the crops, which means that, besides mineral fertilization, it is necessary to also invest in studies with doses of organic matter, because the manures are in many cases the only sources available to family farmers.

This study aimed to evaluate the leaf composition of macronutrients in watermelon plants cultivated in soil with doses of potassium and cattle manure.

\section{Material AND Methods}

The experiment was carried out at the settlement 'Campo Comprido', in Patos, PB, Brazil, from March to June 2012. The climate of the region, according to Köppen's classification, is BSh, semiarid, with mean annual temperatures above $25^{\circ} \mathrm{C}$ and mean annual rainfall below $1000 \mathrm{~mm}$, with irregular rains during the rainy period. In 2012, the annual rainfall was 221 $\mathrm{mm}$ in the experimental area. The soil in the experimental area was classified as Fluvic Neosol.

Before the experiment, soil samples were collected in the layer of $0-20 \mathrm{~cm}$ for chemical and physical characterization (Table 1) according to the methodologies suggested by EMBRAPA (2011).

The experimental design was randomized blocks with three replicates in a $3 \times 5+1$ factorial arrangement, referring to the addition of three doses of cattle manure $(0.0 ; 1,100$ and $\left.2,520 \mathrm{~g} \mathrm{hole}^{-1}\right)$ to increase the organic matter content of the soil, from $0.67 \%$ to 3.0 and $6.0 \%$, five doses of $\mathrm{K}_{2} \mathrm{O}$ in the form of potassium chloride $(0.0 ; 7.5 ; 15.0 ; 22.5$ and $30.0 \mathrm{~kg}$ $\left.\mathrm{ha}^{-1}\right)$ as suggested by Cavalcanti (2008), and an additional treatment without fertilization, as commonly performed in the region. The experimental unit consisted of 21 plants per plot, distributed in three rows of seven plants.

The cattle manure doses were applied as basal fertilization during the opening and preparation of the holes, 30 days
Table 1. Soil chemical and physical characterization in the layer of $0-20 \mathrm{~cm}$

\begin{tabular}{lclc}
\hline \multicolumn{3}{c}{ Chemical attributes } & \multicolumn{3}{c}{ Physical attributes } \\
$\mathrm{pH} \mathrm{H} \mathrm{H}_{2} \mathrm{O}(1: 2.5)$ & 7.02 & Coarse sand $\left(\mathrm{g} \mathrm{kg}^{-1}\right)$ & 312 \\
$\mathrm{P}\left(\mathrm{mg} \mathrm{dm}^{-3}\right)$ & 51.0 & Fine sand $\left(\mathrm{g} \mathrm{kg}^{-1}\right)$ & 475 \\
$\mathrm{~K}^{+}\left(\mathrm{cmol}_{\mathrm{c}} \mathrm{dm}^{-3}\right)$ & 0.40 & Silt $\left(\mathrm{g} \mathrm{kg}^{-1}\right)$ & 137 \\
$\mathrm{Na}^{+}\left(\mathrm{cmol}_{\mathrm{c}} \mathrm{dm}^{-3}\right)$ & 0.30 & Clay $\left(\mathrm{g} \mathrm{kg}^{-1}\right)$ & 76 \\
$\mathrm{H}^{+}+\mathrm{Al}^{3+}\left(\mathrm{cmol}_{\mathrm{c}} \mathrm{dm}^{-3}\right)$ & 0.33 & Dispersed clay $\left(\mathrm{g} \mathrm{kg}^{-1}\right)$ & 13 \\
$\mathrm{Al}^{3+}\left(\mathrm{cmol}_{\mathrm{c}} \mathrm{dm}^{-3}\right)$ & 0.00 & Degree of flocculation (\%) & 82.9 \\
$\mathrm{Ca}^{2+}\left(\mathrm{cmol}_{\mathrm{c}} \mathrm{dm}^{-3}\right)$ & 2.25 & Dispersion index (\%) & 17.1 \\
$\mathrm{Mg}^{2+}\left(\mathrm{cmol}_{\mathrm{c}} \mathrm{dm}^{-3}\right)$ & 1.00 & Soil density $\left(\mathrm{kg} \mathrm{dm}^{-3}\right)$ & 1.53 \\
$\mathrm{SB}\left(\mathrm{Cmol}_{\mathrm{c}} \mathrm{dm}^{-3}\right)$ & 3.93 & Particle density $\left(\mathrm{kg} \mathrm{dm}^{-3}\right)$ & 2.67 \\
$\mathrm{CEC}\left(\mathrm{cmol}_{\mathrm{c}} \mathrm{dm}^{-3}\right)$ & 4.26 & Total porosity $\left(\mathrm{m}^{3} \mathrm{~m}^{-3}\right)$ & 0.43 \\
$\mathrm{~V}(\%)$ & 92.25 & & \\
$\mathrm{SOM}\left(\mathrm{g} \mathrm{kg}^{-1}\right)$ & 6.7 & Textural class & Sandy \\
\hline
\end{tabular}

$\mathrm{SB}=\mathrm{Na}^{+}+\mathrm{K}^{+}+\mathrm{Ca}^{2+}+\mathrm{Mg}^{2+} ; \mathrm{CEC}=\mathrm{SB}+\left(\mathrm{H}^{+}+\mathrm{Al}^{3+}\right) ; \mathrm{V}=(100 \times \mathrm{SB} / \mathrm{CEC}) ; \mathrm{SOM}-$ Soil organic matter

before sowing. The holes were open with dimensions of 0.20 x $0.20 \times 0.30 \mathrm{~m}$, volume of $12 \mathrm{dm}^{3}$ and spacing of $2.0 \times 2.0$ $\mathrm{m}$. The variety 'Crimson Sweet' was selected for cultivation because of its acceptance in the regional market.

According to EMBRAPA (2011), the cattle manure showed the following chemical composition: $\mathrm{pH}=7.90 ; \mathrm{P}=1003 \mathrm{mg}$ $\mathrm{dm}^{-3} ; \mathrm{K}^{+}=3.81 \mathrm{cmol}_{c} \mathrm{dm}^{-3} ; \mathrm{Na}^{+}=0.30 \mathrm{cmol}_{c} \mathrm{dm}^{-3} ; \mathrm{H}^{+}+\mathrm{Al}^{3+}=$ $0.57 \mathrm{cmol}_{\mathrm{c}} \mathrm{dm}^{-3} ; \mathrm{Al}^{3+}=0.0 \mathrm{cmol}_{\mathrm{c}} \mathrm{dm}^{-3} ; \mathrm{Ca}^{2+}=6.90 \mathrm{cmol}_{\mathrm{c}} \mathrm{dm}^{-3}$; $\mathrm{Mg}^{2+}=3.50 \mathrm{cmol}_{c} \mathrm{dm}^{-3}$ and $\mathrm{OM}=38.86 \%\left(388.6 \mathrm{~g} \mathrm{~kg}^{-1}\right)$.

The cattle manure doses were obtained using the following expression:

$$
\mathrm{D}_{\mathrm{CMA}}=\frac{\left[\left(\mathrm{D}_{\mathrm{OMA}}-\mathrm{D}_{\mathrm{OME}}\right) \times \mathrm{Vc} \times \mathrm{ds}\right]}{\mathrm{OMCM}}
$$

where:

$\mathrm{D}_{\mathrm{CMA}}$ - dose of cattle manure to be applied per hole, $\mathrm{g} \mathrm{hole}^{-1}$;

$\mathrm{D}_{\text {OMA }}$ - dose of organic matter to be achieved in the soil, $\mathrm{g} \mathrm{kg}^{-1}$;

$\mathrm{D}_{\text {OME }}$ - dose of organic matter existing in the soil, $\mathrm{g} \mathrm{kg}^{-1}$;

Vc - mean volumetric capacity of the hole, $12 \mathrm{dm}^{3}$;

ds - soil density, $1530 \mathrm{~g} \mathrm{dm}^{-3}$; and,

OMCM - organic matter content existing in the cattle manure, $388.6 \mathrm{~g} \mathrm{~kg}^{-1}$.

The doses of $\mathrm{K}_{2} \mathrm{O}$ in the form of potassium chloride were fractionated as $0,25,50,75$ and $100 \%$ of the maximum dose $\left(30 \mathrm{~kg} \mathrm{ha}^{-1}\right)$ recommended by Cavalcanti (2008) for watermelon in soil with $\mathrm{K}$ contents above $0.30 \mathrm{cmol}_{c}$; thus, $0.0,7.5,15,22.5$ and $30 \mathrm{~kg} \mathrm{ha}^{-1}$ of $\mathrm{K}_{2} \mathrm{O}$ were provided at 40 days after seedlings emergence.

All treatments, except the additional, received nitrogen fertilization $\left(120 \mathrm{~kg} \mathrm{ha}^{-1}\right)$ in the form of urea, divided into two applications, 30 and $90 \mathrm{~kg} \mathrm{ha}^{-1}$ of $\mathrm{N}$, at 20 and 40 days after seedlings emergence (Cavalcanti, 2008). No phosphate fertilization was applied, due to the high values observed in the soil and in the cattle manure.

At sowing, three seeds were planted per hole and, after emergence, when plants showed three pairs of permanent leaves, thinning was performed, leaving only the most vigorous plant per hole.

Irrigation from sowing to emergence was daily performed through sprinklers, maintaining the soil with moisture 
content adequate for the germination process. From emergence to fruiting, irrigation was performed using the conventional sprinkler method, supplying every $48 \mathrm{~h}$ a water depth equal to the reference evaporation obtained by the product of Class A pan evaporation and the factor 0.75 , as suggested by Andrade et al. (2013).

At the beginning of fruiting, 25 leaves ( $5^{\text {th }}$ healthy leaf counted from the apex of the branch) were collected per plot, disregarding the apical tuft, as recommended by Trani \& Raij (1997). After the samples were washed in tap water and submersed in deionized water, the material was placed in paper bags, dried in a forced-air oven at temperature of $65^{\circ} \mathrm{C}$ for $72 \mathrm{~h}$ and ground in a Wiley-type mill (TE-650) using a 20-mesh sieve. Leaf dry matter was analyzed for: total $\mathrm{N}$, determined through the micro-Kjeldahl method (sulfuric digestion); $\mathrm{P}$, through colorimetry of metavanadate; $\mathrm{K}$, through flame emission photometry; $\mathrm{Ca}$ and $\mathrm{Mg}$, through atomic absorption spectrophotometry; and S, through gravimetry of barium sulfate (Malavolta et al., 1997).

The data were subjected to analysis of variance by $\mathrm{F}$ test; the means referring to cattle manure doses were compared by Tukey test at 0.05 probability level and those referring to $\mathrm{K}$ doses by regression. The analysis of contrasts between fertilized treatments and the additional treatment was performed through the Dunnett's test at 0.05 probability level using the statistical program SAS.

\section{Results AND Discussion}

The interaction between doses of $\mathrm{K}$ and cattle manure did not have significant effects on leaf $\mathrm{N}$ content; however, the mean contents observed in Table 2 are within the interval of 25-50 $\mathrm{g} \mathrm{kg}^{-1}$, considered by Trani \& Raij (1997) as adequate for watermelon. Even considering that manure is a source of $\mathrm{N}$ to plants, the absence of significance between the doses of this input for the $\mathrm{N}$ contents of the plants can be explained by the supply of $120 \mathrm{~kg} \mathrm{ha}^{-1}$ of $\mathrm{N}$ in the form of urea in total area, which resulted in equalization of the contents in the plants.

In the treatment with supply of $1,100 \mathrm{~g}$ of cattle manure, the increase in $\mathrm{K}_{2} \mathrm{O}$ doses promoted linear increment of $0.0263 \mathrm{~g} \mathrm{~kg}^{-1}$ in leaf $\mathrm{P}$ content, from 4.8 to $5.6 \mathrm{~g} \mathrm{~kg}^{-1}$ of leaf dry matter, which represents an increment of $16.5 \%$ between plants in soil without and with the highest dose of $\mathrm{K}_{2} \mathrm{O}$ (Figure 1).

This increment is a response of the stimulating action of $\mathrm{K}$ in the release of $\mathrm{P}$ from the soil, which was also reported by El-Bassiony et al. (2012), who observed that K doses in the soil stimulate $\mathrm{P}$ absorption in watermelons and pumpkins.

Table 2. Mean contents of nitrogen $\left(\mathrm{g} \mathrm{kg}^{-1}\right)$ in the leaf dry matter of watermelon cultivated in soil with potassium and cattle manure

\begin{tabular}{cccc}
\hline $\mathbf{K}_{\mathbf{2}} \mathbf{O}$ dose & \multicolumn{3}{c}{ Cattle manure $\left(\mathbf{g ~ h o l e} \mathbf{~}^{-1}\right)$} \\
\cline { 2 - 4 }$\left(\mathbf{k g ~ h a}^{-1}\right)$ & $\mathbf{0}$ & $\mathbf{1 , 1 0 0}$ & $\mathbf{2 , 5 2 0}$ \\
0.0 & 44.3 & 47.3 & 45.5 \\
7.5 & 45.6 & 45.6 & 45.7 \\
15.0 & 47.3 & 44.9 & 47.2 \\
22.5 & 46.7 & 42.2 & 47.8 \\
30.0 & 44.2 & 44.0 & 44.7 \\
Mean & 45.6 & 44.8 & 46.2 \\
\hline
\end{tabular}

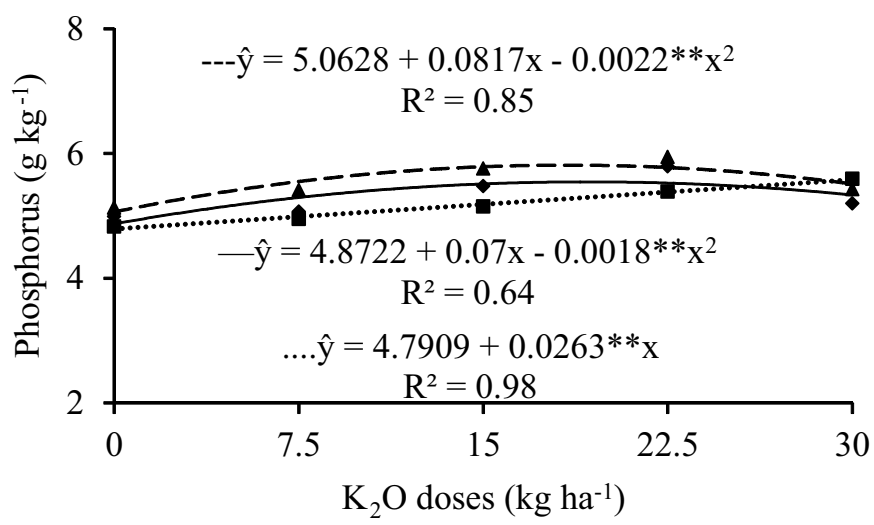

Figure 1. Leaf contents of phosphorus in watermelon cultivated in soil with potassium fertilization, without 0 (-) and with 1,100 (...) and 2,520 $\mathrm{g} \mathrm{hole}^{-1}$ of cattle manure (---)

In the treatments without and with addition of $2,520 \mathrm{~g}$ of cattle manure, leaf $\mathrm{P}$ contents were increased to 5.55 and $5.82 \mathrm{~g} \mathrm{~kg}^{-1}$ of $\mathrm{P}$ for the maximum estimated doses of 19.4 and $18.6 \mathrm{~kg} \mathrm{ha}^{-1}$ of $\mathrm{K}_{2} \mathrm{O}$ (Figure 1). According to Trani \& Raij (1997), leaf P contents varying between 3.0 and $7.0 \mathrm{~g} \mathrm{~kg}^{-1}$ are adequate for the watermelon crop. It is observed, based on the amplitude, that the plants cultivated in the soil without the addition of cattle manure (dose of 0.0 ) and $\mathrm{K}_{2} \mathrm{O}$ were adequate supplied in $\mathrm{P}$.

The increment in leaf $\mathrm{P}$ accumulation was more pronounced in the treatments with the highest dose of cattle manure, 2,520 $\mathrm{g} \mathrm{hole}^{-1}$, probably due to the higher supply of $\mathrm{P}$ with the highest dose of manure and the action of the organic acids produced during the decomposition of organic matter, which blocks $\mathrm{P}$ absorption sites in the soil, decreasing the fixation by the soil (Guppy et al., 2005).

This information is also consistent with Abul-Soud et al. (2010), in the cucumber crop (Cucumis anguria L.), Bindiya et al. (2012) and Santos et al. (2012), who reported increments of $\mathrm{P}$ in the leaf tissue of pumpkin (Cucurbita pepo L.) due to doses of organic inputs applied to the soil.

The adequate supply to plants can be a response of the high content of the nutrient in the soil $\left(51 \mathrm{mg} \mathrm{dm}^{-3}\right)$ as also observed by Geleta et al. (2011) in watermelon plants cultivated in soils with high $\mathrm{P}$ contents.

Leaf $\mathrm{K}$ contents did not differ as a function of the doses of cattle manure and $\mathrm{K}_{2} \mathrm{O}$ added to the soil, but the mean contents are within the range of 20 to $60 \mathrm{~g} \mathrm{~kg}^{-1}$ (Table 3) and, according to Trani \& Raij (1997), plants were balanced with respect to the macronutrient.

Table 3. Mean contents of potassium $\left(\mathrm{g} \mathrm{kg}^{-1}\right)$ in the leaf dry matter of watermelon cultivated in soil with doses of potassium and cattle manure

\begin{tabular}{|c|c|c|c|}
\hline \multirow{2}{*}{$\begin{array}{l}\mathrm{K}_{2} \mathrm{O} \text { dose } \\
\left(\mathrm{kg} \mathrm{ha}^{-1}\right)\end{array}$} & \multicolumn{3}{|c|}{ Cattle manure $\left(\mathrm{g}\right.$ hole $\left.{ }^{-1}\right)$} \\
\hline & 0 & 1,100 & 2,520 \\
\hline 0.0 & 42.4 & 39.2 & 40.9 \\
\hline 7.5 & 39.5 & 38.5 & 43.4 \\
\hline 15.0 & 39.2 & 39.8 & 42.5 \\
\hline 22.5 & 39.0 & 41.0 & 40.9 \\
\hline 30.0 & 42.1 & 41.1 & 40.2 \\
\hline Mean & 40.4 & 39.9 & 41.6 \\
\hline
\end{tabular}


The absence of significant difference of $\mathrm{K}$ contents in leaf dry matter, associated with the adequate nutrition of the plants, means that the contents existing in the soil met the requirement of the crop. Despite the absence of significant differences, the previous supply of this element cannot be neglected, since the soil in the area is sandy and, under irrigation regime, the suppression of $\mathrm{K}$ could cause deficiency of this nutrient due to losses through leaching (Nicolae et al., 2014).

Even considering the plants in the treatments without $\mathrm{K}_{2} \mathrm{O}$ and cattle manure had contents sufficient for their demand, the watermelon crop, for being a plant that demands high amounts of K (Almeida et al., 2012), require the maintenance of sufficient levels of the element in the soil during its cycle, which justifies the recommendation of K by Cavalcanti (2008) even in soil with high contents of the nutrient.

In plants of the treatments without cattle manure, leaf Ca contents linearly increased from 15.53 to $22.1 \mathrm{~g} \mathrm{~kg}^{-1}$, an increment of $42.31 \%$ between plants without and with the highest dose of $\mathrm{K}_{2} \mathrm{O}$ (Figure 2). This result differs from those in the literature, in which the addition of $\mathrm{K}$ to the soil inhibits the availability of Ca to plants (Silva \& Trevizam, 2015).

In the treatments with $1,100 \mathrm{~g} \mathrm{hole}^{-1}$, represented by the equation $\hat{y}=16.44+0.8281 x-0.0277^{\star *} x^{2}\left(R^{2}=0.52\right)$ and 2,520 $\mathrm{g} \mathrm{hole}^{-1}$ of cattle manure (Figure 2), the increment in $\mathrm{K}$ doses increased the values of $\mathrm{Ca}$ in plant leaves to contents of 22.5 and $22.8 \mathrm{~g} \mathrm{~kg}^{-1}$, respectively, at the maximum estimated $\mathrm{K}_{2} \mathrm{O}$ doses of 14.9 and $13.1 \mathrm{~kg} \mathrm{ha}^{-1}$.

The behavior of the data is similar to those reported by Nascimento et al. (2015) for watermelon and Santos et al. (2012) for pumpkin, a plant of the same family of watermelon, who reported increments in leaf $\mathrm{Ca}$ contents due to the increase in doses of organic materials in the soil.

The decrease in $\mathrm{Ca}$ in the treatments with $\mathrm{K}_{2} \mathrm{O}$ doses above the maximum estimated doses can be due to the competitive inhibition between $\mathrm{K}$ and $\mathrm{Ca}$ in the exchange sites of the soil (Silva \& Trevizam, 2015). Still in agreement with the previously mentioned authors, when there are high levels of $\mathrm{K}$ in the soil, the plant grows more, causing reduction in the contents of $\mathrm{Ca}$ due to the dilution effect.

The leafCa contents of $22.1,22.5$ and $22.8 \mathrm{~g} \mathrm{~kg}^{-1}$, respectively, in plants without and with the addition of cattle manure, to increase the content of soil organic matter from $0.67 \%$ to 3.0

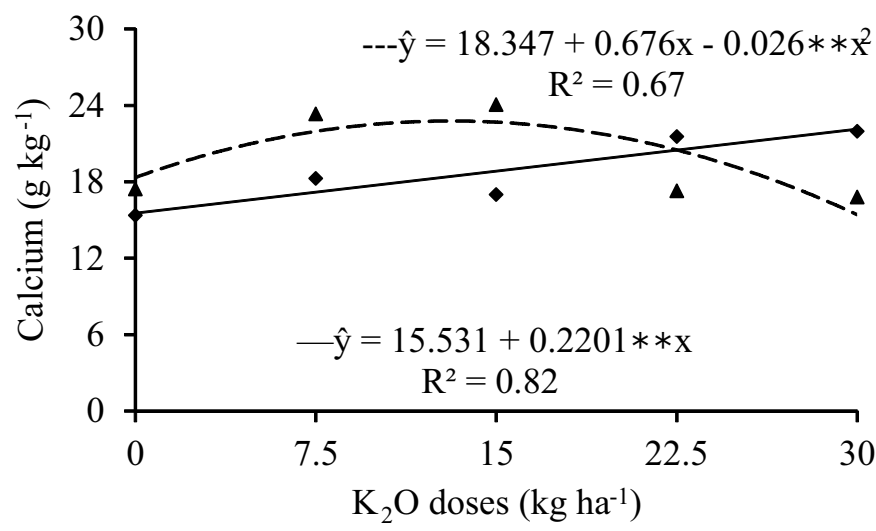

Figure 2. Leaf contents of calcium in watermelon cultivated in soil with $\mathrm{K}_{2} \mathrm{O}$ doses, without - $\mathrm{O}(-)$ and with 2,520 $\mathrm{g} \mathrm{hole}^{-1}$ of cattle manure (--) and $6.0 \%$, are below the lower critical limit that meets the requirement of watermelon, which oscillates between 25 and $50 \mathrm{~g} \mathrm{~kg}^{-1}$ (Trani \& Raij, 1997).

In the treatments without manure $\left(0 \mathrm{~g} \mathrm{hole}^{-1}\right)$ and with the dose of $1,100 \mathrm{~g} \mathrm{hole}^{-1}$, leaf $\mathrm{Mg}$ contents did not fit to any mathematical model as a function of the $\mathrm{K}_{2} \mathrm{O}$ doses, with mean contents of 5.26 and $5.97 \mathrm{~g} \mathrm{~kg}^{-1}$, respectively (Figure 3).

In the treatment with $2,520 \mathrm{~g}$ hole $^{-1}$ of cattle manure, the increment in $\mathrm{K}_{2} \mathrm{O}$ doses caused reduction in $\mathrm{Mg}$ accumulation in the leaf dry matter of the plants. In spite of that, the mean content of $\mathrm{Mg}$ accumulated in the leaves $\left(6.62 \mathrm{~g} \mathrm{~kg}^{-1}\right)$ was numerically higher than those observed in the treatments with 0.0 and $1,100 \mathrm{~g} \mathrm{hole}^{-1}$ of cattle manure. As observed for the Ca content, the absorption of $\mathrm{Mg}$ was also inhibited by the increment in $\mathrm{K}$ doses.

Similar behavior was reported by Santos et al. (2012), studying doses of organic inputs applied to the soil on the leaf $\mathrm{Mg}$ contents in pumpkin. Based on the results in all situations, the contents of $\mathrm{Mg}$ are within the range of 5-12 g $\mathrm{kg}^{-1}$ established as adequate for the watermelon crop (Trani \& Raij, 1997)

Due to the increase in the doses of cattle manure, the contents of $S$ fitted to a quadratic model of polynomial regression (Figure 4). The supply of the doses of $0.0 \mathrm{~g} \mathrm{hole}^{-1}$ $\left(\hat{y}=2.41708+0.02003 x-0.00053^{N S} x^{2} R^{2}=0.58\right), 1,100$ g hole $^{-1}$ $\left(\hat{y}=2.49128+0.02932 x-0.00087^{\star} x^{2} R^{2}=0.53\right)$ and 2,520 $\mathrm{g} \mathrm{hole}^{-1}$ of cattle manure, associated with doses of $18.9,16.8$

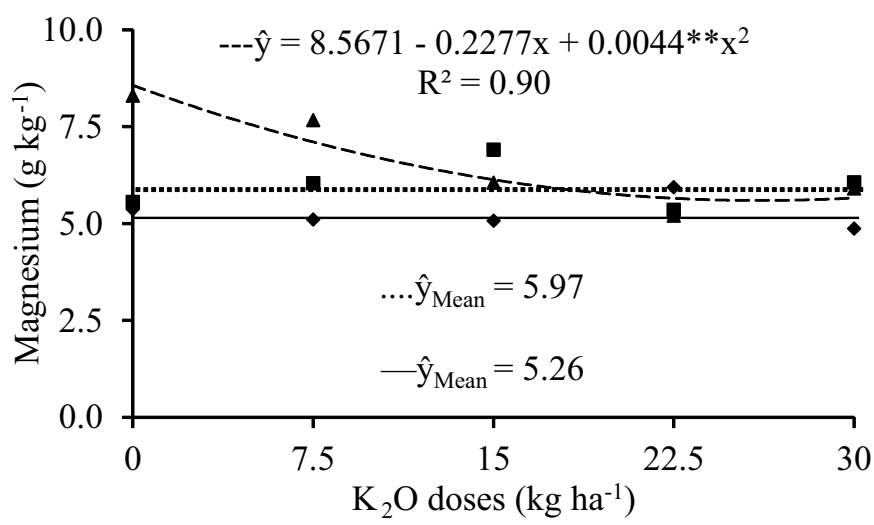

Figure 3. Leaf contents of magnesium in watermelon cultivated with $\mathrm{K}_{2} \mathrm{O}$ doses, without - 0 (-), and with $1,100(\ldots$.$) and 2,520 \mathrm{g} \mathrm{hole}^{-1}$ of cattle manure (---)

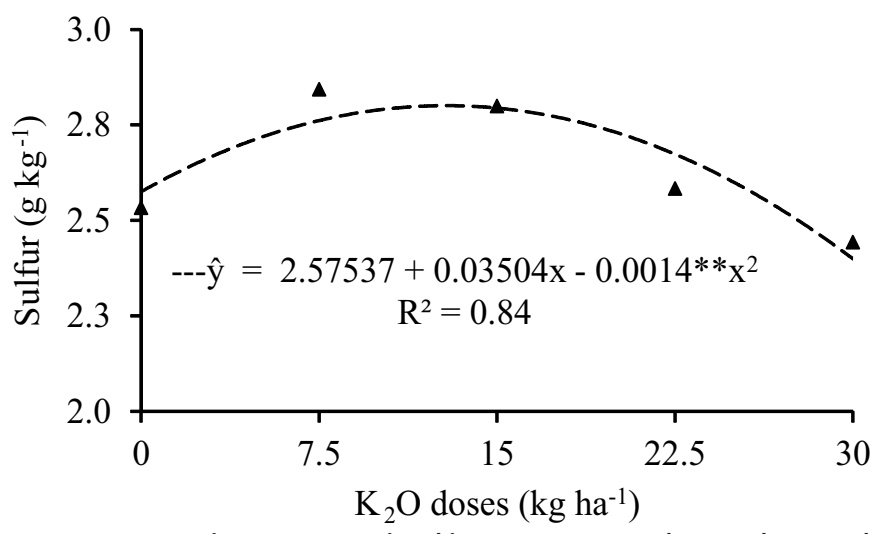

Figure 4. Leaf contents of sulfur in watermelon cultivated in soil with doses of $\mathrm{K}_{2} \mathrm{O}$ and 2,520 $\mathrm{g} \mathrm{hole}^{-1}$ of cattle manure (----) 
and $12.8 \mathrm{~kg} \mathrm{ha}^{-1}$ of $\mathrm{K}_{2} \mathrm{O}$, was responsible, respectively, for the highest contents of S 2.60, 2.73 and $2.79 \mathrm{~g} \mathrm{~kg}^{-1}$ (Figure 4).

The superiority of $S$ contents in the treatments with higher amount of cattle manure, in relation to the lower doses, is due to the fact that the manure is source of $S$ to the plants and, therefore, higher doses contribute with greater increments in the availability of the element in the soil to the plants (Higashikawa et al., 2010).

Watermelon plants, including those in treatments without the addition of cattle manure, showed $\mathrm{S}$ contents in the range of 2.0 to $3.0 \mathrm{~g} \mathrm{~kg}^{-1}$, an indication that they were nutritionally balanced with respect to this element (Trani \& Raij, 1997).

In relation to the test of contrasts between the additional treatment (without fertilizer) and the treatments with fertilization, it is observed that, except for $\mathrm{Ca}$, the leaf contents of the other macronutrients were higher in the treatments that received manure and $\mathrm{K}$ (Table 4 ).

The manure, besides providing elements in small amounts to the soil, especially $\mathrm{N}, \mathrm{P}$ and $\mathrm{S}$, increases the efficiency of mineral fertilization and, therefore, the availability of nutrients to plants (Higashikawa et al., 2010).

For the contents of $\mathrm{N}$ and $\mathrm{K}$ in the leaf tissue, the superiority is mainly due to the supply of urea and potassium chloride. The inferiority of Ca contents in the treatments with $\mathrm{K}_{2} \mathrm{O}$ and manure strengthens the hypothesis of competition between these two elements, compromising the absorption of Ca (Silva \& Trevizam, 2015).

Table 4. Mean contents of N, P, K, Ca and S in the leaf dry matter of watermelon plants fertilized with cattle manure and potassium, for the test of contrasts between the factorial and the additional treatment

\begin{tabular}{lccccc}
\hline \multirow{2}{*}{ Treatments } & $\mathbf{N}$ & $\mathbf{P}$ & $\mathbf{K}$ & $\mathbf{C a}$ & $\mathbf{S}$ \\
\cline { 2 - 6 } & & & $\mathbf{g ~ k g}^{-1}$ \\
Fertilizers & $45.5 \mathrm{a}$ & $5.3 \mathrm{a}$ & $40.6 \mathrm{a}$ & $19.4 \mathrm{~b}$ & $2.60 \mathrm{a}$ \\
Additional & $41.6 \mathrm{~b}$ & $4.9 \mathrm{~b}$ & $38.7 \mathrm{~b}$ & $24.8 \mathrm{a}$ & $2.43 \mathrm{~b}$ \\
\hline
\end{tabular}

Means followed by the same letters in columns do not differ by the Dunnett's test at 0.05 probability level

\section{Conclusions}

1. The supply of cattle manure enhances the absorption of macronutrients by watermelon plants.

2. The dose of $2,520 \mathrm{~g} \mathrm{hole}^{-1}$ of cattle manure promoted better results when associated with 11 and $13 \mathrm{~kg} \mathrm{ha}^{-1}$ of $\mathrm{K}_{2} \mathrm{O}$.

\section{Literature Cited}

Abul-Soud, M.; El-Ansary, D. O.; Hussein, A. M. Effects of different cattle manure rates and mulching on weed control and growth and yield of squash. Journal of Applied Sciences Research, v.6, p.1379-1386, 2010.

Almeida, E. I. B.; Corrêa, M. C. M.; Nóbrega, G. N.; Pinheiro, E. A. R.; Lima, F. F. Crescimento e marcha de absorção de macronutrientes para a cultivar de melancia Crimson sweet. Revista Agro@mbiente, v.6, p.205-214, 2012.

Andrade, A. R. S.; Cruz, A. F. S.; Cavalcante, E. C. S.; Albuquerque, J. C. F.; Souza, W. M. Estimativa da evapotranspiração e dos coeficientes de cultura para diferentes fases de desenvolvimento da melancia. Revista Brasileira de Geografia Física, v.6, p.1417-1429, 2013.
Bindiya, Y.; Srihari, D.; Babu, J. D. Effect of organic manures and biofertilizers on growth, yield and nutrient uptake in gherkin (Cucumis anguria L.). Journal Research ANGRAU, v.40, p.2629, 2012.

Cavalcanti, J. C. P. Recomendações de adubação para o estado do Pernambuco (2a aproximação). 3.ed. Recife: IPA, 2008. 212p.

El-Bassiony, A. M.; Fawzy, Z. F.; Glala A. A. Responses of two watermelon cultivars to supplemental potassium application and fruit thinning. Journal of Applied Sciences Research, v.8, p.2732-2740, 2012.

EMBRAPA - Empresa Brasileira de Pesquisa Agropecuária. Centro Nacional de Pesquisa de Solos. Manual de métodos de análise do solo. 3.ed. Rio de Janeiro: EMBRAPA, 2011. 230p.

Geleta, S. B.; Briand, C.; Womack, H. E.; Brinsfield, R. B.; Mulford, F. R. Is phosphorus fertilization necessary for watermelon production on high phosphorus soils? Canadian Journal of Plant Science, v.86, p.205-211, 2011. http://dx.doi.org/10.4141/ P04-093

Gonsalves, M. V. I.; Pavani, L. C.; Cecílio Filho, A. B.; Feltrim, A. L. Índice de área foliar e produtividade da melancieira com frutos sem sementes em função do espaçamento entre plantas e de $\mathrm{N}$ e K aplicados por fertirrigação. Científica, v.9, p.25-33, 2011.

Guppy, C. N.; Menzies. N. W.; Moody, P. W.; Blamey, F. P. C. Competitive sorption reactions between phosphorus and organic matter in soil: A review. Australian Journal of Soil Research, v.43, p.189-202, 2005. http://dx.doi.org/10.1071/SR04049

Higashikawa, F. S.; Silva, C. A.; Bettiol, W. Chemical and physical properties of organic residues. Revista Brasileira de Ciência do Solo, v.34, p.1742-1752, 2010. http://dx.doi.org/10.1590/S010006832010000500026

Malavolta, E.; Vitti, G. C.; Oliveira, S. A. Avaliação do estado nutricional das plantas: Princípios e aplicações. 2. ed. Piracicaba: POTAFOS, 1997. 201p.

Nascimento, J. A. M.; Souto, J. S.; Cavalcante, L. F.; Oliveira, F. T.; Mendonça, V.; Albuquerque Júnior, A. M.; Medeiros, S. A S. Macronutrientes na cultura da melancia cultivada em Neossolo com esterco bovino. Revista Brasileira Ciências Agrárias, v.10, p.224-229, 2015. http://dx.doi.org/10.5039/agraria.v10i2a5058

Nicolae, I.; Camen, D.; Lascu, N.; Marieta, P. Research regarding influence of organic fertilization on the physiological processes intensity in watermelon plants. Journal of Horticulture, Forestry and Biotechnology, v.18, p.78-83, 2014.

Santos, M. R.; Sediyama, M. A. N.; Moreira, M. A.; Megguer, A. C.; Vidigal, S. M. Rendimento, qualidade e absorção de nutrientes pelos frutos de abóbora em função de doses de biofertilizante. Horticultura Brasileira, v.30, p.160-167, 2012. http://dx.doi. org/10.1590/S0102-05362012000100027

Silva, D. S. O.; Leite, D. T.; Galdino, G. O.; Costa, C. C. Descrição das atividades desenvolvidas nas hortas urbanas no município de Pombal. Revista Verde de Agroecologia e Desenvolvimento Sustentável, v.6, p.6-16, 2011.

Silva, M. L. S.; Trevizam, A. R. Interações iônicas. Informações Agronômicas, n.149, p.10-16, 2015.

Trani, P. E.; Raij, B. van. Hortaliças. In: Raij, B. van.; Cantarela, H.; Quaggio, J. A.; Furlani, A. M. C. (ed.). Recomendação de adubação e calagem para o estado de São Paulo. 2.ed. Campinas: IAC, 1997. p.157-164. Boletim 100 